\title{
USING MULTISPECTRAL IMAGING TO IMPROVE BERRY HARVEST FOR WINE MAKING GRAPES
}

\section{UTILIZAÇÃO DA IMAGIOLOGIA MULTIESPECTRAL PARA MELHORAR A VINDIMA DE UVAS DESTINADAS À PRODUÇÃO DE VINHO}

\author{
G. Iatrou $^{1}$ *, S. Mourelatos ${ }^{1}$, S. Gewehr ${ }^{1}$, S. Kalaitzopoulou ${ }^{1}$, M. Iatrou ${ }^{1}$, Z. Zartaloudis ${ }^{2}$ \\ ${ }^{1}$ Ecodevelopment S.A., 57010, Filyro, Thessaloniki, Greece. \\ ${ }^{2}$ Agroecosystem L.P., N. Moudania, Chalkidiki, Greece. \\ * Corresponding author: Tel: +306972916770, Fax: +302310677550, e-mail: iatrou@ecodev.gr
}

(Received 23.02.2016. Accepted 07.04.2017)

SUMMARY

The determination of time for grape harvest is probably the most important decision for wine making producers, because grapes are not climacteric fruits and if they are harvested before fully ripe their quality is compromised. This is because sugar content, aroma and color compounds increase only before harvest for non-climacteric fruits. The current practice for determining berry ripeness includes measurements of berry samples for total soluble solids (TSS) and pH, but this procedure is time consuming and laborious. On the other hand, with the development of unmanned aerial vehicles (UAV) and modern ultralight cameras the grower can now obtain data rapidly and also spatial information for crop's physiological status at farm scale. Berry samples were collected from grapevines ( $c v$. Malagousia) and their reflectance spectra were used to estimate TSS and $\mathrm{pH}$ by Multiple Linear Regression (MLR) and Support Vector Machine (SVM). The highest classification accuracy was achieved using the SVM model. Moreover, berries taken by grapevines with low Carotenoid Reflectance Index 2 (CRI2) had higher TSS, pH and terpenes, and gave wine with higher alcohol by volume. The importance for constructing a model for predicting TSS in berries is obvious, because this can aid in the prediction of wine quality. The current work is a preliminary compilation of methodologies for making a monitoring tool of berry ripeness, using statistical techniques, remote sensing and crop physiological data.

\section{RESUMO}

A determinação da época de vindima é provavelmente a decisão mais importante para os produtores vinícolas porque as uvas não são frutos climatéricos e se forem vindimadas antes de estarem completamente maduras, a sua qualidade fica comprometida. Isto ocorre porque o teor de açúcar, assim como os compostos responsáveis pelo aroma e pela cor aumentam apenas antes da colheita de frutos não climatéricos. A prática atual para determinar a maturação da uva inclui medições de amostras de uva quanto a sólidos solúveis totais (TSS) e pH, mas este procedimento é demorado e trabalhoso. Por outro lado, com o desenvolvimento de veículos aéreos automatizados (UAV) e câmaras ultraleves modernas, o produtor pode agora obter dados rapidamente e também informação espacial sobre o estado fisiológico da cultura à escala da propriedade. Foram recolhidas amostras de uvas de videiras ( $c v$. Malagousia) e os seus espetros de reflexão foram utilizados para estimar o TSS e o pH através de Regressão Linear Múltipla (MLR) e de uma Máquina de Vetores de Suporte (SVM). A precisão da classificação mais alta foi obtida com a utilização do modelo SVM. Além disso, as uvas de videiras com baixo Índice de Reflexão de Carotenoide 2 (CRI2) alcançaram valores de TSS, pH e terpenos mais elevados, dando origem a vinho com mais álcool por volume. A importância para a construção de um modelo de previsão de TSS em uvas é óbvia, porque pode auxiliar na previsão da qualidade do vinho. O presente trabalho é uma compilação preliminar de metodologias para criar uma ferramenta de monitorização da maturação da uva, utilizando técnicas estatísticas, deteção remota e dados fisiológicos da cultura.

Key words: Berry ripening, remote sensing, Support Vector Machine, Carotenoid Reflectance Index.

Palavras-chave: Maturação da uva, deteção remota, Máquina de Vetores de Suporte, Índice de Reflexão de Carotenoide.

\section{INTRODUCTION}

The fast-paced development of UAV technology providing ultralight systems having high autonomy and maneuverability, the ability to land and take off everywhere and fly at low altitudes, in combination with modern ultralight multispectral cameras, can aid growers to collect high quality spatial data at low cost (Johnson et al., 2003; Matese and Gennaro, 2015). The information obtained by these systems will be increasingly used in precision viticulture, as grapevine products have high commodity value and

\section{3}

This is an Open Access article distributed under the terms of the Creative Commons Attribution License

(http://creativecommons.org/licenses/by/4.0), which permits unrestricted use, distribution, and reproduction in any medium, provided the original work is properly cited. 
also the spatial distribution of wine making grapevines plays an important role in the quality of the final product (Hall et al., 2002; Lamb et al., 2004). The physical (including soil texture and field water capacity), chemical properties and the slope of the soil, the microclimate and the sunlight exposure, delineate specific zones within a larger field parcel, which influence the character of the wine and can be defined as micro-terroir (Dougherty, 2012). These specific zones can be determined today using remote sensing. Another important consideration is that remote sensing can allow manipulation of the vines by the grower to express the micro-terroir because it offers the potential for differential management of the vines at specific zones.

The time of grape harvest is also an important concern for viticulturists, as grapes are nonclimacteric fruits. Thus, grapes have to be picked at the optimum level of ripeness. However, there are specific zones within the vineyard, where the ripening process is significantly different compared to others. These specific zones can probably provide grapes which express more special geographic qualities of an identified terroir (Deloire, 2013). Thus, using very high resolution imagery the viticulturist could express at a greater extent a typical terroir related character by adopting the following: a) keep fruit from identified zones within a vineyard separate at harvest, b) manage the vines of specific delineated zones and c) determine the time of picking for obtaining berries with enriched sugar content, flavor and color compounds.

Previous works have pointed out that the relative concentration of carotenoid (carotenoids per unit of chlorophyll) increase at the onset of leaf senescence due to environmental stress (Peñuelas et al., 1994, 1995; Munné-Bosch and Alegre, 2000; Munné-Bosch and Peñuelas, 2003). For this reason, the changes of leaf carotenoid content are commonly used as an index for the diagnosis of the physiological status of vegetation. Results in relation to the optical spectra of senescing leaves due to pathological or environmental stress or other developmental processes have been extensively reported in literature. In contrast, autumnal senescence of leaves, which coincides with grape ripeness, has not been studied in depth in terms of leaf optics (Keskitalo et al., 2005). Data presented by Merzlyak and Gitelson (1995) show that carotenoids tend to decline during autumnal senescence but slower compared to chlorophyll. This results in an increase in the ratio of carotenoids to chlorophyll.

Gitelson (2012) recommends two relatively narrowbands (red edge: 700-720 nm, green: 540-560 $\mathrm{nm}$ ), one narrowand (centered at $510 \mathrm{~nm}$ with a bandwith of $10 \mathrm{~nm}$ ) and one relatively broad band (NIR: $760-900 \mathrm{~nm}$ ) for the determination of carotenoid content in tree species (e.g. beech, chestnut and maple). This is because the red edge and green bands are more sensitive to variable chlorophyll content, as the depth of the light penetration was found to be higher in the red edge and green bands compared to other bands. The Carotenoid Reflectance Index 1 and 2 (CRI1, CRI2) are indices that estimate the carotenoid content using the mathematical difference of reciprocal reflectance in the green and in the red edge, respectively, and the reciprocal reflectance in a band centered at $510 \mathrm{~nm}$ (Gitelson et al., 2002). This difference is also multiplied by reflectance at NIR. The scope of these indices is to remove the effect of chlorophyll on the estimation of carotenoids, as carotenoids and chlorophylls absorb in the blue range (400 to $500 \mathrm{~nm}$ ) and thus it is difficult to estimate carotenoid concentration independently from chlorophyll concentration using nondestructive techniques (Peñuelas et al., 1995). A previous study by Zartaloudis et al. (2015) showed that the CRI2 index was more appropriate index compared to other carotenoid indices for tracking leaf carotenoid changes of olives due to Verticillium wilt infection. Work conducted by Sebela et al. (2012) showed that the CRI1 index was the most suitable index for detecting the increase in the carotenoid content of grapevine leaves due to Plasmopara viticola infection. Moreover, Meggio et al. (2010) showed that grape quality indicators are correlated with the CRI2 index.

The objective of the present work is to study the potential of the CRI2 index to detect the spatial variability of the ripeness of grapes ( $c v$. Malagousia). The CRI2 was selected over the CRI1 index because the multispectral camera used for this study was set to record in the red edge and not in the green band. This was due to the findings from a previous study where both CRI1 and CRI2 were assessed (Zartaloudis et al., 2015).

\section{MATERIAL AND METHODS}

An experiment was conducted in 2015 in a commercial vineyard about 60 ha $\left(22^{\circ} 59^{\prime} 13.80716 "\right.$, $\left.40^{\circ} 26^{\prime} 59.20304 "\right)$ located in Epanomi, $25 \mathrm{~km}$ of south east Thessaloniki. Field data collection involved 12 subplots within the 5 year old field parcel of $c v$. Malagousia. The subplots included two rows of vineyards. A flight was conducted on $18^{\text {th }}$ July 2015 over the experimental area using a UAV (Ebee, senseFly, Switzerland,) and a multispectral camera (Multispec 4C, Airinov, France) for collecting 
multispectral data over the field parcels. Camera's four spectral bands were modified to acquire images at 510, 660, 710 and $790 \mathrm{~nm}$ with a spectral resolution of 10 to $20 \mathrm{~nm}$. The CRI2, the Normalized Difference Vegetation Index (NDVI), the Pigment Specific Simple Ratio Carotenoids (PSSRCc) and the Structure Intensive Pigment Index (SIPI) were calculated for the scopes of this study (Rouse et al., 1974; Penuelas et al., 1995; Blackburn, 1998; Gitelson et al., 2002). The indices were adapted to enable calculation with the modified multispectral camera. The pixel size of the camera was equal to 12 $\mathrm{cm}$ on the ground and the camera's lens-to-focus distance was equal to $13 \mathrm{~mm}$. The CRI2, NDVI, PSSRCc and SIPI were calculated according to the following equations:

$$
\text { CRI2 }=((1 / \text { R510 })-(1 / R 710)) \times R 790
$$

$$
\begin{aligned}
\text { NDVI }= & (\mathrm{R} 790-\mathrm{R} 660) /(\mathrm{R} 790+\mathrm{R} 660) \\
& \mathrm{PSSRC} C=\mathrm{R} 790 / \mathrm{R} 510 \\
\mathrm{SIPI} & =(\mathrm{R} 790-\mathrm{R} 510) /(790+\mathrm{R} 660)
\end{aligned}
$$

The subplots were divided in grapevines having high and low carotenoid content. A hypothesis was adopted that grapevines with low CRI2 values (high carotenoid content) would have higher sugar content compared to grapevines having high CRI2 values (low carotenoid content). Berries were collected then from grapevines having different levels of carotenoids, as shown in Figure 1. Six berry samples were collected from the subplots having high carotenoid content (blue color in Figure 1B) and six samples were collected from the subplots having low carotenoid content (red color in Figure 1B).
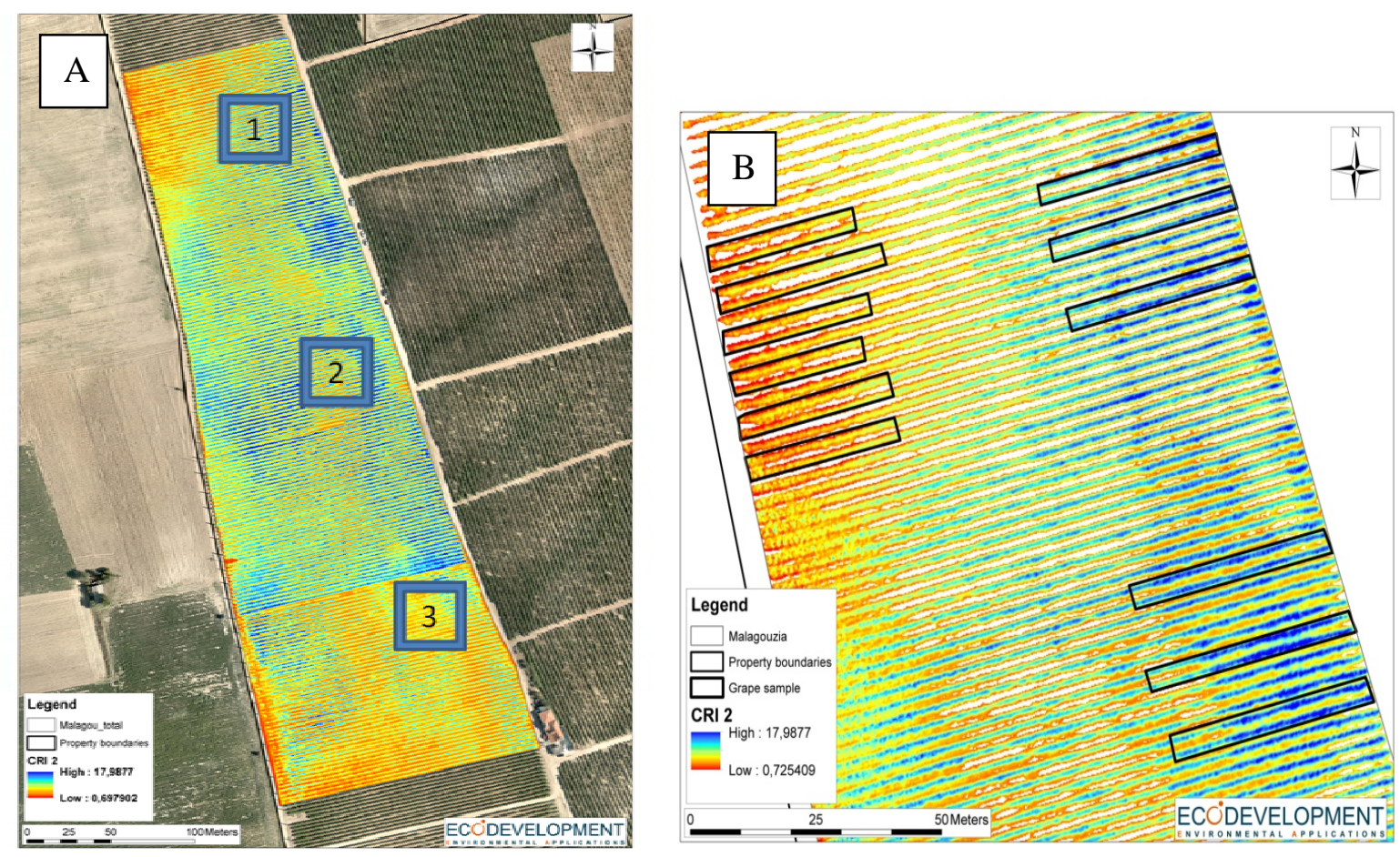

Figure 1. A: Three field parcels (1, 2, 3) grown with Malagousia grapevines including grapevines aging 5, 12 and 3 years old, respectively. Grape samples were taken by the first parcel. B: Subplots in the field parcel comprising of grapevines having high (on the left, red) and low (on the right, blue) carotenoid content.

A: Três parcelas de terreno $(1,2,3)$ cultivadas com videiras Malagousia, incluindo videiras com 5,12 e 3 anos de idade, respetivamente. Foram recolhidas amostras de uvas da primeira parcela. B: Subparcelas na parcela do terreno compostas por videiras que possuem um alto teor de carotenoides (à esquerda, a vermelho) e baixo teor de carotenoides (à direita, a azul).

From now on berry samples collected from the red area of the map will be called ripe and berry samples collected from the blue area of the map will be called unripe. A total of 20 berries from each subplot were picked for determining Total Soluble Solids (TSS) and $\mathrm{pH}$ on $18^{\text {th }}$ July 2015. TSS was used as an estimate of sugar content of the fruit, because sugars are the major soluble \% solid in the fruit. Fruits were 
homogenized using a hand-held blender and total soluble solids and $\mathrm{pH}$ were measured directly from the must using a hand-held refractometer and a $\mathrm{pH}$ meter. Two samples of must from grapevines having low CRI2 values and two samples of must from grapevines having high CRI2 values were sent to an accredited laboratory (Laboratoire Burgundia Oenologie, Beaune, France) for analysis of terpenes (alpha-terpineol, linalool, geraniol, nerol, betacitronellol, oxide, cis-rose oxide, beta-damascenone, genanyl acetate, neryl acetate, farsenol, myrcene and alpha-pinene).

\section{Statistical Analysis}

Differences in TSS and $\mathrm{pH}$ of the berries collected from the subplots were analyzed using ANOVA. Multiple Linear Regression (MLR), Support Vector Machine (SVM), Nonlinear Regression Models (NRM), Principal Component Analysis (PCA) and Partial Least Squares (PLS) were used for constructing a model for the prediction of berry TSS and $\mathrm{pH}$ based on the reflectance values of the grapevines. Two models were built based on multiple liner regression (MLR) and support vector machine (SVM). The performance of accuracy was highest for the SVM model when polynomial kernel of degree 3 was used. For validating the performance of the models the Goodman and Kruskal's Gamma for ordinal attributes of the Tanagra data mining research software was used (Rakotomalala, 2005). The $\gamma$ value using the Goodman and Kruskal's gamma method measures the strength of association between the predicted and the real values. The values range from 1 and +1 . A value of zero indicates no association.

\section{RESULTS AND DISCUSSION}

As shown in Figure 1A the CRI2 index shows a considerable variability both within, as well as among, the three parcels of various age. Statistical analysis indicates that berries harvested by grapevines with low CRI2 values (high carotenoid content, had significantly higher TSS content $(p=0.006)$ compared to berries harvested by grapevines with high CRI2 values Figure 2). Despite that no significant difference in the $\mathrm{pH}$ of the must was found between the berries harvested from the grapevines with low CRI2 compared to those with high CRI2, there was a trend that the $\mathrm{pH}$ of the berries from the grapevines with low CRI2 had higher $\mathrm{pH}$ values. The NDVI was significantly reduced for the grapevines having low CRI2 values (Figure 2B). There were trends showing that the PSSRCc index was reduced for the grapevines having low CRI2 values and the SIPI index was increased, but not statistically significant (Figure 3). The difference between the grapevines having low and high CRI2 for the SIPI index just failed to be significant at the $95 \%$ level of probability. There were also trends showing that the must samples taken by grapevines with low CRI2 had higher concentration of terpenes (particularly linalool, which gives the smell of lavender in wines) compared to grapevines with high CRI2 (Figure 4).
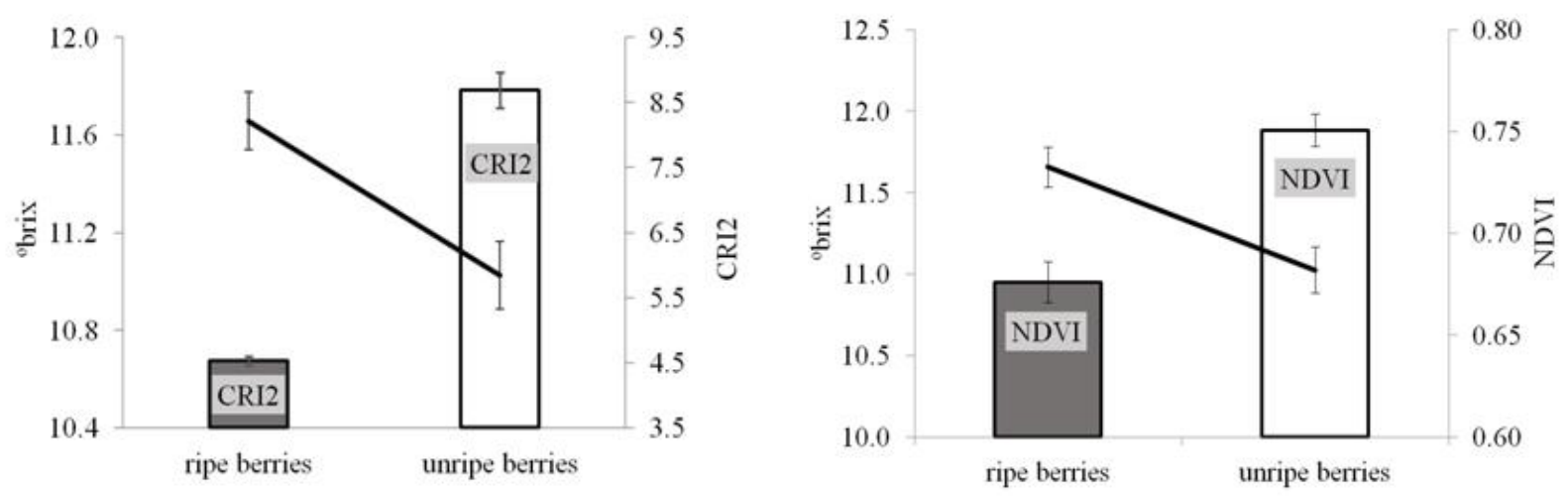

Figure 2. Comparison between the CRI2 (on the left) and NDVI (on the right) with TSS in ripe and unripe berries. Error bars display s.e.m.

Comparação entre CRI2 (à esquerda) e NDVI (à direita) com TSS em uvas maduras e verdes. As barras de erro exibem s.e.m. 

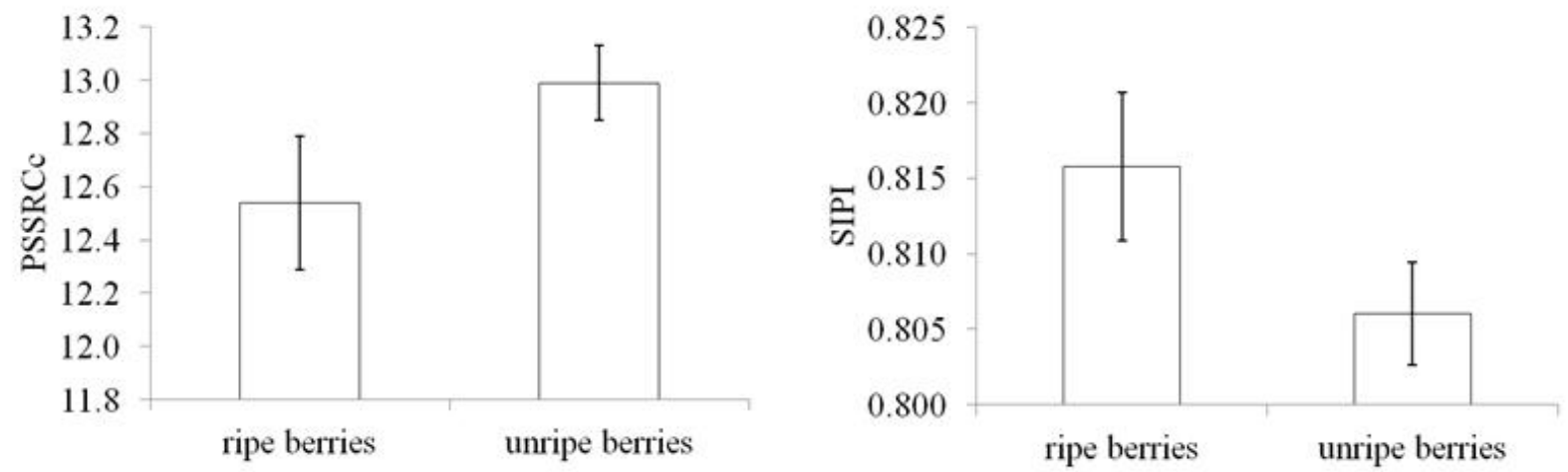

Figure 3. PSSRCc (on the left) and SIPI (on the right) of the grapevines having low and high CRI2 values (ripe and unripe, respectively). Error bars display s.e.m.

PSSRCc (à esquerda) e SIPI (à direita) das videiras tendo valores CRI2 baixos e altos (maduras e verdes, respetivamente). As barras de erro exibem s.e.m.

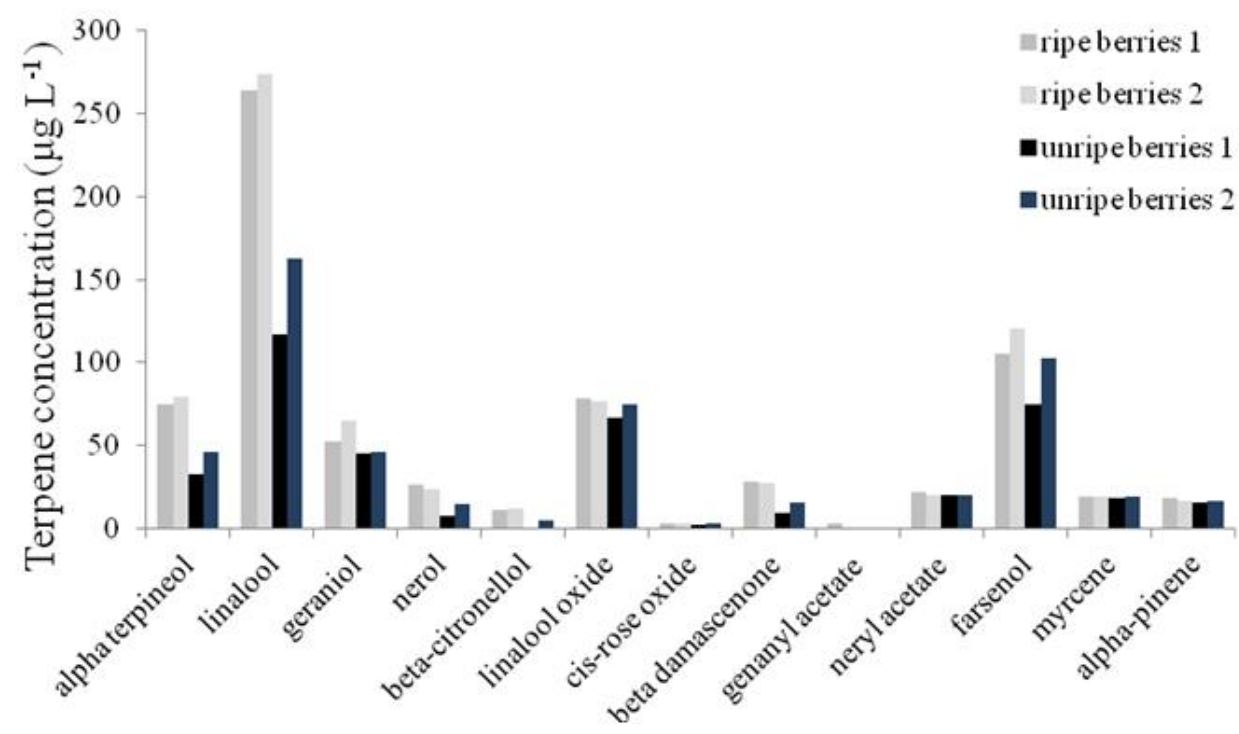

Figure 4. Concentration of terpenes in the must of berry samples taken by grapevines with high carotenoid content (ripe berries) and low carotenoid content (unripe berries).

Concentração de terpenos no mosto das amostras de uvas de videiras com alto teor de carotenoides (uvas maduras) e baixo teor de carotenoides (uvas verdes).

According to the results of the present study, the model obtained by the SVM analysis provided better prediction for berry TSS and $\mathrm{pH}$ (Figures 5 and 6). The $\gamma$ value from the Goodman and Kruskal's gamma method for the predicted TSS values using MLR against real TSS values was 0.68 , while the $\gamma$ value for the predicted TSS values using SVM against real TSS values was 0.71 . Furthermore, the $\gamma$ value for the predicted $\mathrm{pH}$ values using the MLR against real $\mathrm{pH}$ values was 0.61 , while the $\gamma$ value for the predicted $\mathrm{pH}$ values using SVM against real $\mathrm{pH}$ values was 0.64 . Thus, the SVM method proved to be superior compared to the MLR method. The PCA and the PLS methods did not gave different predictions compared to the MLR method, as expected, because the variables of the equation (CRI2, NDVI, PSSRCc and SIPI) were few. 

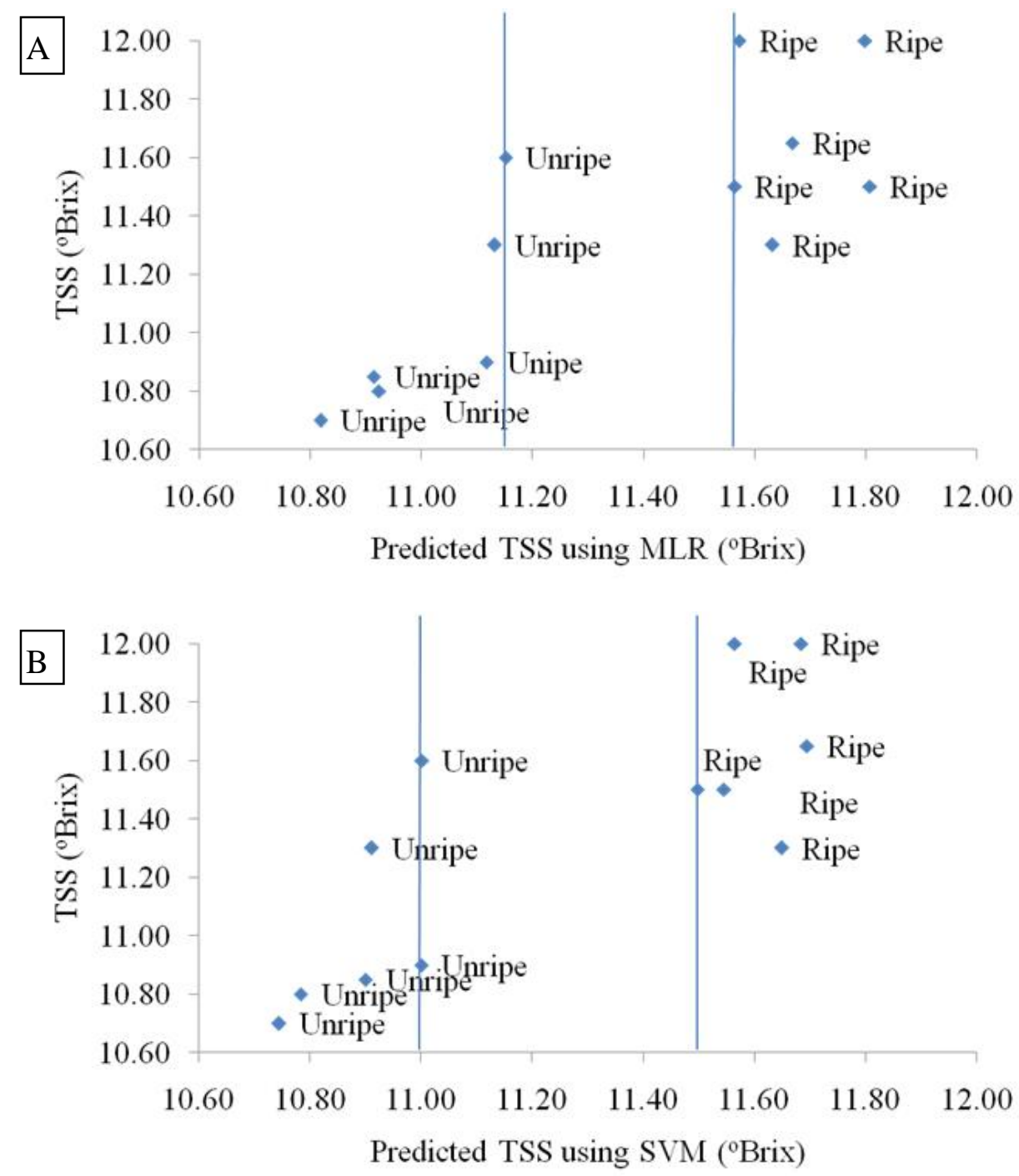

Figure 5. Correlation for predicted TSS using A) MLR and B) SVM against berry TSS values. The vertical lines show that the difference between the predicted TSS values of the berries having low and high CRI2 values, characterized as ripe and unripe, respectively, is larger using SVM compared to MLR.

Correlação para TSS previsto utilizando A) MLR e B) SVM em contraste com os valores TSS das uvas. As linhas verticais indicam que a diferença entre os valores de TSS previstos das uvas com valores CRI2 baixos e altos, caracterizadas como maduras e verdes, respetivamente, é maior utilizando SVM em comparação com MLR.

Chlorophyll tends to decline more rapidly than carotenoids during leaf senescence. Thus, spectral indices, such CRI1 and CRI2, that determine carotenoids taking into account chlorophyll or indices that determine the ratio of carotenoids to chlorophyll could probably track the physiological changes occurring in leaves due to autumnal senescence, which coincides with grape ripeness. In other words, despite that the amount of carotenoids tended to decrease during autumnal leaf senescence, the ratio of carotenoids to chlorophyll increased because carotenoids are decreased less compared to chlorophyll (Munné-Bosch and Alegre, 2000; Sims and Gamon, 2002). As a result, increased levels of carotenoids per unit of chlorophyll can be observed due to autumnal leaf senescence. This allows us to determine the stage of leaf senescence, which according to the results of the present study correlates with berry ripeness (Figure 2). 

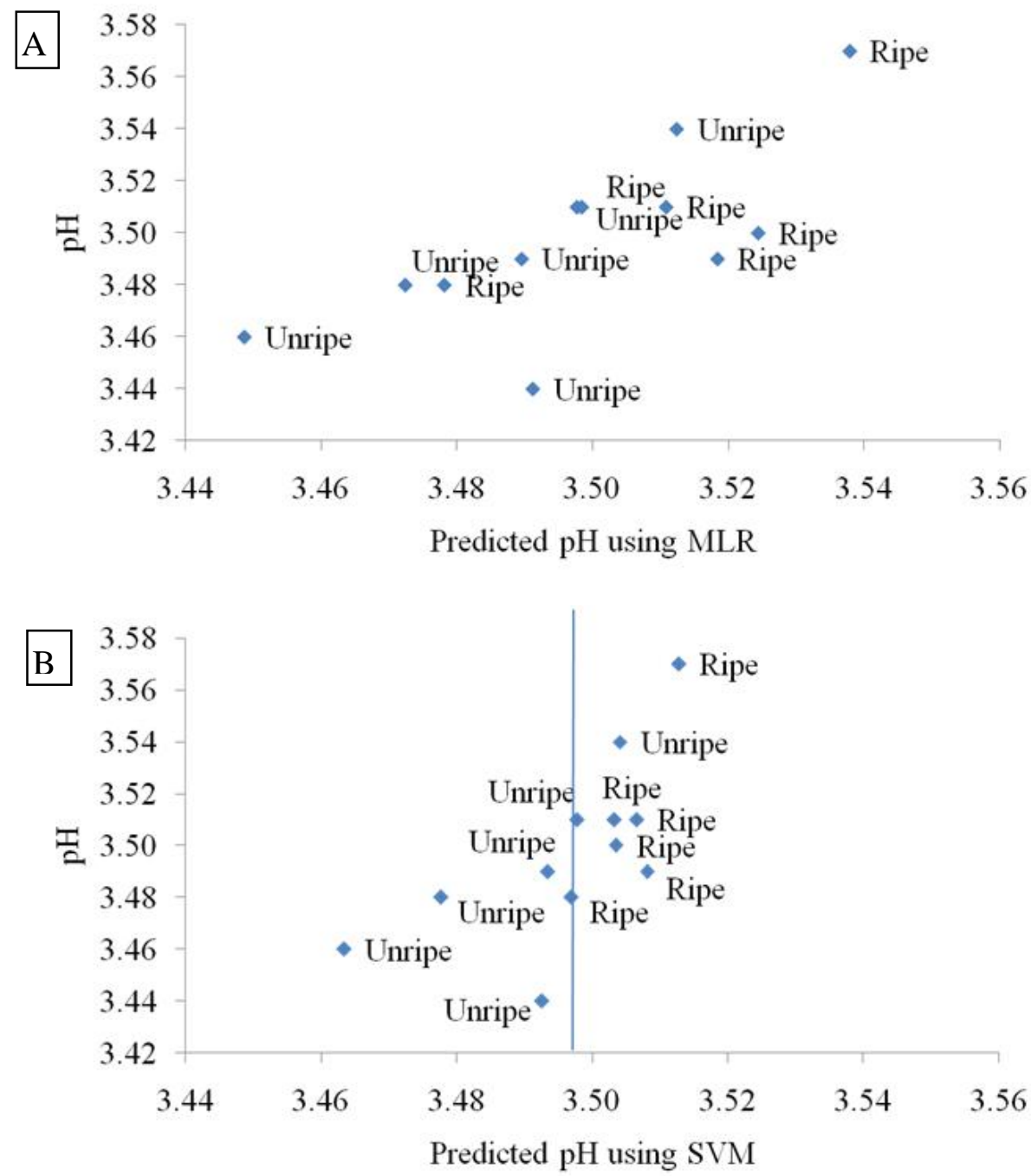

Figure 6. Correlation for predicted $\mathrm{pH}$ using A) MLR and B) SVM against berry pH values. The vertical line at the bottom graph shows a theoretical threshold for classification of the berries in relation to their ripeness according to their $\mathrm{pH}$. The berries coming from grapevines having low and high CRI2 values are characterized as ripe and unripe, respectively.

Correlação entre o pH previsto utilizando A) MLR e B) SVM e os valores do pH das uvas. A linha vertical no gráfico abaixo apresenta um limite teórico para a classificação das uvas em relação ao seu estado de maturação de acordo com o seu pH. As uvas provenientes de videiras com valores de CRI2 baixos e altos são caracterizados como maduro e verde, respetivamente.

According to Sebela et al. (2012) the chlorophyll content and CRI1 values increased with increased concentration of pigments. The CRI1 index measures carotenoids in leaves similarly to the CRI2 index (Gitelson, 2012). Hence, high CRI1 values were correlated with healthy leaf tissue. Moreover, the CRI index was inversely correlated with the carotenoid to chlorophyll ratio in a rainforest, and thus tracked the physiological stress of forest canopies (Asner et al. 2005, 2006). Zartaloudis et al. (2015) also showed that increased CRI2 values indicated decreased olive canopy stress, which differentiated olive trees according to their infection level by Verticillium wilt. Results presented here show that indeed the carotenoids in leaves increased in the grapevines giving berries with higher ${ }^{\circ}$ brix, as these grapevines gave lower CRI2 values and trends of lower PSSRCc and higher SIPI values, compared to the grapevines giving berries with lower ${ }^{\circ}$ brix (Figure 3). The PSSRCc and the SIPI indices are inversely and 
positively correlated with the carotenoid to chlorophyll ratio, respectively (Peñuelas et al, 1995; Blackburn, 1998).

The model constructed by the SVM analysis can be used for the prediction of berry TSS based on spectra data of the grapevines. This model could be a valuable tool for the viticulturist, because it could provide the spatial variability of berry ripeness of a specific vineyard. Furthermore, according to the results of the present study the wine produced by zones having low CRI2 values will probably be enriched in terpenes (aroma) and flavor, and could lead to terroir delineation.

\section{CONCLUSIONS}

Berry ripeness is a significant parameter for wine making grapes, because the level of berry ripeness determines the time of harvest. However, with the current level of understanding for determining the level of berry ripeness, including TSS and $\mathrm{pH}$ measurements in the must of harvested berries, the procedure is time consuming and lacks spatial information. By using spectral indices correlating to

\section{REFERENCES}

Asner G., Carlsonm K., Martin, R., 2005. Substrate age and precipitation effects on Hawaiian forest canopies from spaceborne imaging spectroscopy. Remote Sens. Environ., 9, 457-467.

Asner G.P., Martin R.E., Carlson K.M., Rascher U., Vitousek P.M., 2006. Vegetation-climate interactions among native and invasive species in Hawaiian rainforest. Ecosystems, 9, 1106-1117.

Blackburn A.G., 1998. Spectral indices for estimating photosynthetic pigment concentrations: a test using senescent tree leaves. Int. J. Remote Sens., 19, 657-675.

Deloire A., 2013. New method to determine optimal ripeness for white wine styles. Practical Winery Journal, Winter 2013, 75-79.

Dougherty P.H., 2012. Introduction to the geographical study of viticulture and wine production BT - In: The geography of wine: regions, terroir and techniques. 3-36. Dougherty H. P. (ed.). Springer, Netherlands.

Gitelson A., 2012. Nondestructive estimation of foliar pigment (chlorophylls, carotenoids, and anthocyanins) contents. In: Hyperspectral remote sensing of vegetation. 141-166. Thenkabail P., Lyon J., Huete A. (eds). CRC Press, Boca Raton.

Gitelson A.A., Zur Y., Chivkunova O.B., Merzlyak M.N., 2002. Assessing carotenoid content in plant leaves with reflectance spectroscopy. Photochem. Photobiol., 75, 272-281.

Hall A., Lamb D.W., Holzapfel B., Louis J., 2002. Optical remote sensing applications in viticulture - a review. Aust. J. Grape Wine Res., 8, 36-47.

Johnson L.F., Herwitza, S., Dunagana, S., Lobitza, B., Sullivana, D., Slyea R., 2003. Collection of ultra high spatial and spectral resolution image data over California vineyards with a small UAV. leaf carotenoids, the prediction of berry ripeness and the spatial determination of the berry TSS content can now be possible.

Using a very high resolution remote sensing image, which includes different zones of grapevines based on the predicted berry TSS values, the viticulturist could: a) adopt differential harvesting of the vineyard, according to the level of berry ripeness in each zone; b) determine the time of harvest for each different zone, by using repeated remote sensing images; c) leave out during harvest zones of very delayed ripeness and; $d$. investigate the reasons of the delayed ripeness in specific zones by taking samples or changing the management strategy the following years.

\section{ACKNOWLEDGMENTS}

The authors would like to thank Mr. Evangelos Gerovassiliou, Mr. Argiris Gerovassiliou, Mr. Argiris Argiriou and Mrs. Alexandra Papadaki, from "ktima Gerovassiliou" for their help and contribution to the present work.

In: Proceedings of the International Symposium on Remote Sensing of Environment, Honolulu, HI, USA, 10-14 November 2003; p. 3.

Keskitalo J., Bergquist G., Gardeström P., Jansson S., 2005. A cellular timetable of Autumn senescence. Plant Physiol., 139, $1635-1648$.

Lamb D.W., Weedon M.M., Bramley R.G.V., 2004. Using remote sensing to predict grape phenolics and colour at harvest in a Cabernet Sauvignon vineyard: Timing observations against vine phenology and optimizing image resolution. Aust. J. Grape Wine Res., 10, 46-54.

Matese A., Gennaro S.F. 2015. Technology in precision viticulture: a state of the art review. Intern. J. Wine Res., 7, 69-81.

Meggio F., Zarco-Tejada P.J., Núñez L.C., Sepulcre-Cantó G., González M.R., Martín, P. 2010. Grape quality assessment in vineyards affected by iron deficiency chlorosis using narrow-band physiological remote sensing indices. Remote Sens. Environ., 114, 1968-1986.

Merzlyak M.N., Gitelson A., 1995. Why and what for the leaves are yellow in Autumn? On the interpretation of optical spectra of senescing leaves (Acerplatanoides L.). J. Plant Physiol., 145, 315320.

Munné-Bosch S., Alegre L., 2000. The xanthophyll cycle is induced by light irrespective of water status in field-grown lavender (Lavandula stoechas) plants. Physiol. Plantarum, 108 $147-151$.

Munné-Bosch S., Penuelas J., 2003. Photo-and antioxidative protection during summer leaf senescence in Pistacia lentiscus L. grown under mediterranean field conditions. Ann. Bot., 92, 385391.

Peñuelas J., Gamon J.A., Fredeen A.L., Merino J., Field C.B., 1994. Reflectance indices associated with physiological changes in 
nitrogen- and water-limited sunflower leaves. Remote Sens. Environ.. 48, 135-46.

Peñuelas J., Baret F., Filella I., 1995. Semi-empirical indices to assess carotenoids/chlorophyll a ratio from leaf spectral reflectance. Photosynthetica, 31, 221-230.

Rakotomalala R., 2005. TANAGRA: un logiciel gratuit pour l'enseignement et la recherche. In: Actes de EGC'2005, RNTI-E-3, vol. 2, pp.697-702.

Rouse J.W., Jr Deering D.W., Schell J.A., Harlan J.C., 1974. Monitoring the vernal advancement and retrogradation (green wave effect) of natural vegetation. NASA/GSFC type III final report: Greenbelt, Maryland, NASA, 371 p.
Sebela D., Olejnickova J., Zupcanova A., Sotolar R., 2012. Response of grapevine leaves to Plasmopara viticola infection by means of measurement of reflectance and fluorescence signals. Acta Univ. Agric. Silvic. Mendelianae Brun., 60, 229-238.

Sims D.A., Gamon J.A., 2002. Relationships between leaf pigment content and spectral reflectance across a wide range of species, leaf structures and developmental stages. Remote Sens. Environ., 81, 337-54.

Zartaloudis Z.D., Iatrou M., Savvidis G., Savvidis K., Glavenas D., Kalogeropoulos K., Kyparissi S., 2015. Early and timely detection of Verticillium dahliae in olive growing using remote sensing. El Aceite de Oliva, Actas Simposio Expoliva 2015, Jaen, Espana, 6-8 Mayo. 